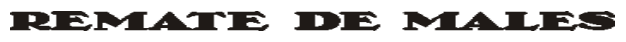

Campinas-SP, v.38, n.2, pp. 473-476, jul./dez. 2018

\title{
TRADUÇão EM ENSAIO
}

Um dos primeiros volumes da revista Remate de Males ("Território da Tradução", de 1984) tinha a tradução de poesia como tema e como ideia de repertório. O presente número temático entende revisitar essa proposta, trazendo reflexões sobre tradução juntamente com exercícios de tradução de poesia, ou relacionados com questões poéticas. Em outras palavras, o Dossiê “Tradução em ensaio" (expressão que explora a cumplicidade entre o ensaio como forma de escrita e a experimentação como abordagem possível do traduzir) resulta do desejo de reabrir o espaço de uma revista especializada para a experiência tradutória, ao mesmo tempo em que procura tratar essa proposta de modo mais entranhado com o debate universitário contemporâneo, para o qual o ensaio se tornou um gênero de escrita comum de divulgação e de militância intelectual.

É verdade que a tradução nunca deixou de ser, a seu modo, um discurso de interpretação e de crítica. Não por acaso, ela faz parte do horizonte intelectual e criativo de boa parte dos colaboradores deste número. Contudo, do ponto de vista de seu estatuto como objeto do conhecimento, é preciso lembrar que, desde pelo menos os anos 1980, a tradução vem sendo reconhecida, não apenas como modo subsidiário de acesso à literatura estrangeira, mas como forma legítima e mesmo privilegiada de relação com a discussão teórica. Aquilo que, no Brasil, ganhou o nome de "teoria da tradução" abriu-se a um campo (eventualmente tratado como disciplinar) no qual a reflexão sobre objetivos particulares envolve problemas de ordem histórica, teórica e filosófica. Tornou-se, por essa razão, em contexto universitário, um lugar privilegiado da interdisciplinaridade, no qual a tradição de reflexão sobre 
o traduzir abre extensões revitalizantes para aspectos da Filosofia, da Psicanálise, da História, da Linguagem.

Ao mesmo tempo, é preciso reconhecer o exercício da tradução (e da tradução de poesia, em especial) não apenas como um espaço da aplicação de determinadas ideias sobre o texto, não apenas como uma ampliação de repertórios supostamente definidos e bem delimitados, mas como um campo de ação que modifica nossa relação com a tradição e com a criação literária. A radicalidade por vezes necessária à lógica da tradução de poesia não está apartada da permanente reformulação dos vínculos entre escrita e realidade, tampouco do processo pelo qual a poesia produzida em determinada época encontra seus estímulos, suas referências, seus desafios.

O conjunto de artigos que aqui apresentamos traz uma mescla notável dessa vivência da poesia, associando o trabalho criativo com a pesquisa consistente sobre determinados autores, obras ou questões. Iniciamos com a memória de um trabalho já amplamente reconhecido, o da tradução de Galáxias para o francês, por Inês Oseki-Dépré, ao qual estão associados (na seção Documentos), manuscritos de Haroldo de Campos e cartas trocadas entre autor e tradutora. Ainda dentro do Dossiê, seguem-se trabalhos de grande envergadura, como a tradução da poesia de Emily Dickinson (por Adalberto Muller) ou do livro Charmes [Feitiços] de Paul Valéry (por Álvaro Faleiros e Roberto Zular) - projetos que terão seguramente, muito em breve, impacto perceptível no campo editorial e na própria leitura brasileira desses poetas.

A atualidade da pesquisa em tradução é contemplada de várias maneiras. Propostas bastante diferentes entre si, como a tradução da poesia amorosa do Egito antigo (por Guilherme Gontijo Flores), da balada em jargão de François Villon (por Daniel Padilha Pacheco da Costa) ou da carta-poema de Marguerite de Navarre (por Luciana Villas Boas e Sérgio Alcides) têm em comum o esforço de trazer ao português um repertório sui generis de textos. Cada uma delas, nas suas especificidades, ajuda o leitor contemporâneo a entender e a apreciar obras tradicionalmente pouco acessíveis ou pouco conhecidas.

Alguns trabalhos são exemplos de modalidades distintas de relação com a língua, na poesia recente de várias tradições literárias. Patricia Peterle, ao discutir sua tradução de um poema de Enrico Testa, explora a experiência de tradução como um mergulho na relação entre línguas. Já José Roberto Andrade Feres, no mesmo gesto em que elabora uma noção 
de tradução como prática que tende mais à "conversa" do que à "conserva”, comenta sua experiência de traduzir dois poemas de Leslie Kaplan, destacando a tarefa de traduzir de um texto escrito em três línguas. Por sua vez, Marianna Daudt, Andrei Cunha e Michelle Buss partem do conceito de "exofonia" para traduzir poemas de Tawada Yôko, publicados originalmente em japonês e em alemão.

Por fim, o presente Dossiê da Remate de Males oferece também uma pequena amostra da diversidade crítica com que a tradução é vivida e pensada contemporaneamente. Paulo Henriques Britto revisita analiticamente sua tradução para um poema de Stephen Crane, feita há três décadas, para a qual se valera de elementos do "Navio Negreiro", de Castro Alves. Gilles Jean Abes, ao ensaiar a tradução do parágrafo inicial de L'étranger, de Albert Camus, circunscreve, nos termos de uma "luz estrangeira", o estranhamento desconcertante que matiza a novela camusiana. Já Helena Franco Martins, impactada pelo modo como se dá o enlace entre leitura, tradução e escrita poética em Autobiography of Red: A Novel in Verse, de Anne Carson, traduz o poema de Emily Dickinson que epigrafa essa obra.

De modo geral, ainda que os trabalhos não se filiem à mesma compreensão do sentido e da prática da tradução (cada um deles mostrando a produtividade de determinado ponto de vista sobre a tarefa do tradutor), faz parte da reflexão atual a reavaliação de noções e critérios tradicionais, que tem como consequência não apenas uma alteração no modo de ler e de traduzir, mas também a produção de determinados deslocamentos sobre aquilo que é um original, sobre aquilo que cabe traduzir, sobre a escolha da língua a partir da qual um poema deve ser traduzido, sobre o estatuto da língua na qual se escreve ou sobre as razões que nos levam a traduzir.

Se, por um lado, um revigorante trabalho crítico e filológico pode ser identificado em vários dos artigos (como, por exemplo, em "Situação de Valéry traduzido no Brasil” ou em "Costura \& Sutura”), por outro, a opção de traduzir a partir de outras traduções, recusando a ideia de original materialmente único (“Antes do original”), a partir de duas línguas estrangeiras ("Exofonia do hóspede") ou, ainda, de traduzir a tradução de um poema de Baudelaire (em "Die Autonomie des Übersetzers", de Rafael Guimarães Tavares da Silva, que fecha o Dossiê) mostra claramente algumas das consequências trazidas por formas contemporâneas de 
conceber a atividade tradutória, as quais vêm abrindo novos repertórios, além de novos desafios teóricos e práticos.

\author{
Marcos Siscar (Unicamp) \\ Maurício Mendonça Cardozo (UFPR) \\ Marcelo Jacques de Moraes (UFRJ)
}

